\title{
Gambaran Kesesuaian Pola Makan, Aktivitas Fisik, Dan Waktu Istirahat Tenaga Kesehatan Kota Surabaya Di Masa Pandemi COVID-19
}

\author{
Amelliya Nur Heriyana, Farapti, dan Stefania Widya Setyaningtyas \\ Universitas Airlangga Jalan DR. Ir. Soekarno, Mulyorejo, Kota Surabaya, Jawa Timur \\ Email: amelliya.nur.heriyana-2016@fkm.unair.ac.id
}

\begin{abstract}
Abstrak
Coronavirus Disease (COVID-19) merupakan jenis virus yang baru ditemukan pada akhir tahun 2019 di Wuhan, China. Dalam waktu kurang dari satu bulan, COVID-19 telah menyebar hingga keluar China dan telah menginfeksi setidaknya 800 orang. Kemudian pada tanggal 11 Maret 2020, WHO menetapkan COVID-19 sebagai suatu kondisi pandemi. Tenaga kesehatan tergolong kelompok rentan untuk tertular COVID-19 dikarenakan kontak langsung dengan pasien COVID-19. Pemerintah telah mengeluarkan Pedoman Gizi Seimbang (PGS) di masa pandemi COVID-19 terkait pola makan, aktivitas fisik, dan waktu istirahat untuk menjaga daya tahan tubuh tenaga kesehatan maupun kelompok masyarakat lainnya. Maka dari itu, penelitian ini bertujuan untuk melihat pola makan, aktivitas fisik, dan waktu istirahat tenaga kesehatan Kota Surabaya di masa pandemi COVID-19. Penelitian ini berupa penelitian survey deskriptif dengan jumlah responden sebanyak 92 tenaga kesehatan di Kota Surabaya yang diambil menggunakan teknik purposive sampling. Pengumpulan data dilakukan secara online menggunakan alat berupa kuesioner dengan media google form selama \pm 1 bulan. Hasil survey menunjukkan bahwa dari 92 orang tenaga kesehatan, sebanyak 59 tenaga kesehatan $(64,51 \%)$ telah dapat dikategorikan sesuai dengan pedoman gizi seimbang (PGS) sedangkan 33 orang lainnya termasuk dalam kategori tidak sesuai dengan PGS. Berdasarkan hasil penelitian, dapat disimpulkan bahwa telah lebih dari setengah tenaga keseatan memiliki pola makan, aktivitas fisik, dan waktu istirahat yang sesuai dengan PGS.
\end{abstract}

Kata Kunci: COVID-19, pedoman gizi seimbang (PGS), tenaga kesehatan

\begin{abstract}
Coronavirus Disease (COVID-19) is a type of virus that was only discovered at the end of 2019 in Wuhan, China. In less than a month, COVID-19 has spread beyond China and has infected at least 800 people. Then on March 11, 2020, WHO determined COVID-19 as a pandemic condition. Healthcare workers are classified as a vulnerable group to contract COVID-19 due to direct contact with COVID-19 patients. The government has issued Balanced Nutrition Guidelines (PGS) during the COVID-19 pandemic related to diet, physical activity, and rest periods to maintain the immune system of health workers and other community groups. Therefore, this study aims to see the diet, physical activity, and rest time for Surabaya city health workers during the COVID-19 pandemic. This research is a descriptive survey research with the number of respondents as many as 92 health workers in the city of Surabaya who were taken using purposive sampling technique. The data was collected online using a questionnaire with google form media for \pm 1 month. The survey results showed that out of 92 healthcare workers, 59 healthcare workers (64.51\%) were categorized according to the guidelines for balanced nutrition (PGS) while 33 others were categorized as not in accordance with PGS. Based on the results of the study, it can be concluded that more than half of the healthcare workers have a diet, physical activity, and rest periods that are in accordance with PGS.
\end{abstract}

Keywords: COVID-19, balanced nutrition guidelines (PGS), healthcare worker http://ejournal.urindo.ac.id/index.php/kesehatan

Article History :

Sumbitted 01 Jaunari 2021, Accepted 30 Juni 2021, Published 30 Juni 2021 


\section{PENDAHULUAN}

Coronavirus Disease atau yang dikenal dengan COVID-19 merupakan jenis penyakit infeksius yang dapat menular dari satu inang ke inang lainnya dan baru dideteksi pada akhir tahun 2019 (World Health Organization (WHO), 2020). Organisasi WHO secara resmi mengumumkan bahwa COVID-19 disebabkan oleh Severe Acute Respiratory Syndrome Coronavirus-2 (SARS-CoV-2) yang pertama kali ditemukan di Wuhan, China (Hafeez et al., 2020). Puncaknya, pada tanggal 11 Maret 2020 WHO menetapkan COVID-19 sebagai pandemi (World Health Organization (WHO), 2020)

Indonesia memiliki kasus COVID-19 pertama yang tercatat pada tanggal 2 Maret 2020 yang menginfeksi dua orang di Depok, Jawa Barat (Yuliana, 2020). Berawal dari penemuan kasus pertama tersebut, selanjutnya kasus COVID-19 terus diperbaharui oleh pemerintah hingga pada tanggal 10 Agustus 2020 terdapat sekitar 127 ribu kasus terkonfirmasi, 82.236 kasus sembuh, dan 5765 kasus meninggal (Gugus Tugas Percepatan Penanganan COVID-19, 2020)

Di Indonesia, Jawa Timur menjadi salah satu Provinsi dengan angka COVID-19 tertinggi dengan menduduki urutan kedua setelah DKI Jakarat yaitu sebanyak 25.330 orang atau sekitar 20,2\% dari total kasus keseluruhan di Indonesia (Gugus Tugas Percepatan Penanganan COVID-19, 2020). Berdasarkan peta sebaran COVID-19 yang dirilis oleh Pemprov
Jawa Timur, Kota Surabaya menjadi kota pertama dengan jumlah kasus tertinggi yaitu sebesar 9751 kasus positif dengan 6.166 kasus sembuh (Jatim Tanggap COVID-19, 2020). Tingginya kasus COVID-19 di seluruh dunia menyebar dan telah menginfeksi berbagai kalangan termasuk tenaga medis yang maju sebagi garda terdepan dan menjadi kelompon rentan untuk terinfeksi (Barrer et al., 2020)

Sebuah penelitian menyebutkan bahwa dari keseluruhan kasus COVID-19 yang ada di beberapa negara, 10,1\% dalam kasus adalah menyerang tenaga kesehatan (Sahu et al., 2020). Di Indonesia sendiri laporan resmi yang dikeluarkan oleh Kemenkes pada tanggal 28 Maret 2020 telah terdapat 61 tenaga kesehatan terpapar COVID-19 namun untuk lebih lanjut belum ada laporan resmi dari Kemenkes atau yang berwewenang (Kemenkes RI, 2020). Menurut beberapa hasil penelitian yang telah dilakukan, tenaga kesehatan yang terinfeksi COVID-19 dapat disebabkan oleh beberapa faktor, diantaranya ketersediaan APD; kontak dengan pasien COVID-19; jam kerja terlalu lama; asupan makanan yang tidak adekuat; konsumsi suplementasi; dan jam tidur tenaga kesehatan yang kurang optimal (Benarba et al., 2020; Mhango et al., 2020; Singh et al., 2020; Zhang et al., 2020)

$$
\text { Upaya pencegahan dan penularan }
$$
COVID-19 pada tenaga kesehatan harus dilakukan dan diperketat untuk meminimalisir terus meningginya kasus COVID-19 pada tenaga kesehatan. Kementerian Kesehatan Republik 
Indonesia telah mengeluarkan Panduan Gizi Seimbang Pada Masa Pandemi COVID-19. Dalam panduan tersebut, terdapat tiga hal utama yang harus diubah dan dilakukan untuk meningkatkan daya tahan tubuh, yaitu : Makan makanan bergizi seimbang, istirahat yang cukup, dan rutin berolahraga. (Kemenkes, 2020). Oleh karena itu, penerapan pedoman gizi sembang (PGS) menjadi hal yang penting untuk dilakukan utamanya oleh kelompok rentan seperti tenaga kesehatan yang menjad objek dalam penelitian ini.

\section{METODE}

Penelitian ini menggunakan dua metode, yaitu studi literature dan metode survey. Studi literature digunakan untuk mencari referensi teori yang relevan dengan hasil deskripsi data yang diperoleh dari hasil survey. Adapun survey menjadi metode utama yang dugunakan peneliti untuk mendapatkan data dari responden. Survei dilakukan oleh peneliti dengan responden tenaga kesehatan Kota Surabaya yang selanjutnya akan diolah oleh peneliti.

Instrumen pengumpulan data yang digunakan dalam penelitian adalah berupa kuesioner pada media google form yang disebarluaskan melalui media sosial lain, seperti whatsapp, instagram, line, dan twitter.

HASIL

Hasil berupa karakteristik responden disajikan dalam tabel 1.1. Diketahui bahwa sebagian besar responden berjenis kelamin perempuan $(71,7 \%)$ dengan usia terbanyak adalah berada pada rentang usia 18-30 tahun $(47,8 \%)$. Adapun distribusi jenis pekerjaan tenaga kesehatan menyebar menjadi beberapa jenis pekerjaan yang mana perawat memiliki persentase tertinggi jika dibandingkan dengan jenis pekerjaan lainnya $(32,6 \%)$ yang sebagian besar berada pada instansi rumah sakit (62\%). Selain itu, diketahui pula bahwa sebanyak $44,6 \%$ responden memiliki status gizi normal.

Tabel 1. Distribusi Karakteristik

\section{Responden}

\begin{tabular}{lcc}
\multicolumn{1}{r}{ Variabel } & $\begin{array}{c}\text { Jumlah } \\
(\mathrm{n})\end{array}$ & $\begin{array}{c}\text { Persentase } \\
(\%)\end{array}$ \\
\hline $\begin{array}{l}\text { Jenis Kelamin } \\
\text { Perempuan }\end{array}$ & 26 & 28,3 \\
Laki-laki & 66 & 71,7 \\
\hline Usia & & \\
18-30 & 44 & 47,8 \\
$31-45$ & 36 & 39,2 \\
$46-59$ & 12 & 13,0
\end{tabular}

Pekerjaan

$\begin{array}{lcc}\text { Ahli Gizi } & 3 & 3,3 \\ \text { Laboratorium } & 20 & 21,7 \\ \text { Medis } & & \\ \text { Apoteker } & 1 & 1,1 \\ \text { Asisten Perawat } & 1 & 1,1\end{array}$

Bedah

$\begin{array}{lll}\text { Dokter Gigi } & 1 & 1,1 \\ \text { Promosi } & 1 & 1,1\end{array}$

Kesehatan

$\begin{array}{lll}\text { Psikolog } & 2 & 2,2\end{array}$

$\begin{array}{lll}\text { Sanitarian } & 2 & 2,2\end{array}$ 


\begin{tabular}{lcc} 
Teknobiomedik & 1 & 1,1 \\
Bidan & 10 & 10,9 \\
Perawat & 30 & 32,6 \\
Kesehatan & 5 & 5,4 \\
Masyarakat & & \\
Dokter & 15 & 16,2 \\
Umum/Spesialis & & \\
\hline Instansi & & \\
Rumah sakit & 57 & 62 \\
Klinik & 6 & 6,5 \\
Laboratorium & 3 & 3,3 \\
Praktik mandiri & 1 & 1,1 \\
Puskesmas & 25 & 27,5 \\
\hline Status Gizi & & \\
Kurang & 2 & 2,2 \\
Normal & 41 & 44,6 \\
Overweight & 19 & 20,7 \\
Obesitas & 30 & 32,6 \\
\hline
\end{tabular}

Tabel 2. Distribusi Pola Makan Makan

Responden di masa COVID-19

\begin{tabular}{cccc}
\hline $\begin{array}{c}\text { Variabel Pola } \\
\text { Makan }\end{array}$ & Kategori & $\mathrm{n}$ & $\%$ \\
\hline \multirow{2}{*}{ Pola makan } & Sesuai & 59 & 64,1 \\
& Tidak sesuai & 33 & 34,8 \\
Konsumsi & Sesuai & 51 & 55,4 \\
sarapan & Tidak sesuai & 41 & 44,6 \\
Konsumsi & Sesuai & 79 & 85,9 \\
makan utama & Tidak sesuai & 13 & 14,1 \\
Konsumsi & Sesuai & 27 & 29,3 \\
snack & Tidak sesuai & 65 & 70,7 \\
Konsumsi air & Sesuai & 65 & 70,7 \\
putih & Tidak sesuai & 27 & 29,3 \\
Kesesuaian & Sesuai & 25 & 27,2
\end{tabular}

\begin{tabular}{cccc}
\hline $\begin{array}{c}\text { Variabel Pola } \\
\text { Makan }\end{array}$ & Kategori & $\mathrm{n}$ & $\%$ \\
\hline $\begin{array}{c}\text { dengan isi } \\
\text { piringku }\end{array}$ & Tidak sesuai & 67 & 72,8 \\
Kesulitan & Sesuai & 46 & 50 \\
mengakses & & & \\
makanan di & Tidak sesuai & 46 & 50 \\
tempat kerja & & & \\
Konsumsi & Sesuai & 90 & 97,8 \\
suplemen & Tidak sesuai & 2 & 2,2 \\
& Sesuai & 87 & 94,6 \\
Perokok aktif & Tidak sesuai & 5 & 5,4 \\
\hline
\end{tabular}

Tabel 2 merupakan tabel distribusi pola makan dengan beberapa variabel pendukung yang telah diadaptasi berdasarkan pedoman Gizi Seimbang (PGS). Dari tabel di atas, dapat diketahui bahwa belum semua variabel pola makan dilaksanakan secara tertib oleh responden, utamanya di masa pandemi COVID19 seperti saat ini. Walaupun begitu, pola makan responden sebanyak lebih dari setemgah jumlah responden $(64,1 \%)$ telah memiliki pola makan yang sesuai dengan PGS dengan distribusi masing-masing variabel telah tercantum dalam tabel 2 .

Tabel 3. Distribusi Aktivitas Fisik Saat di Masa COVID-19

\begin{tabular}{cccc}
\hline $\begin{array}{c}\text { Variabel } \\
\text { Aktivitas Fisik }\end{array}$ & Kategori & $\mathrm{n}$ & $\%$ \\
\hline \multirow{3}{*}{ Aktivitas fisik } & Sesuai & 33 & 35,9 \\
& Tidak & 59 & 64,1 \\
& sesuai & &
\end{tabular}


Jurnal Bidang IImu Kesehatan

\begin{tabular}{cccc} 
Frekuensi & Sesuai & 10 & 10,9 \\
olahraga & Tidak & 82 & 89,1 \\
& sesuai & & \\
& Sesuai & 32 & 34,8 \\
Durasi olahraga & Tidak & 60 & 65,2 \\
& sesuai & & \\
\hline
\end{tabular}

Tabel 3 di atas menggambarkan terkait distribusi aktivitas fisik responden selama masa pandemi COVID-19. Berbeda dengan kesesuaian berdasarkan pola makan dengan lebih dari setengah responden memiliki pola makan yang sesua dengan PGS, pada aktiivtas fisik, diketahui bahwa lebih dari setengah responden memiliki aktivitas fisik yang tidak sesua dengan anjuran PGS. Sebanyak 59 orang atau sekitar $64,1 \%$ responden memiliki pola aktivitas fisik yang tidak sesuai dengan PGS.

Tabel 4. Distribusi Waktu Istirahat Responden di Masa COVID-19

\begin{tabular}{ccc}
\hline Kategori & $\mathrm{n}$ & $\%$ \\
\hline Sesuai & 60 & 65,2 \\
Tidak & 32 & 34,8 \\
Sesuai & & 100 \\
Total & 92 & \\
\hline
\end{tabular}

Berdasarkan tabel 4, diketahui bahwa sebanyak 60 orang $(65,2 \%)$ responden telah memiliki waktu tidur yang telah sesuai dengan anjuran yang tercantum dalam PGS yaitu sekitar 6-8 jam sehari.

Tabel 5. Penerapan Pedoman Gizi Sembang Saat COVID-19

\begin{tabular}{cccc}
\hline Variabel & Kategori & $\mathrm{n}$ & $\%$ \\
\hline Pedoman & Sesuai & 59 & 64,1 \\
Gizi & Tidak & 33 & 35,9 \\
Seimbang & Sesuai & & \\
(PGS) & Total & 92 & 100 \\
\hline
\end{tabular}

Kesesuaian penerapan pedoman gizi seimbang (PGS) oleh tenaga kesehatan dianalisis berdasarkan 3 variabel utama yaitu pola makan, aktivitas fisik, dan waktu istirahat yang dijalani oleh tenaga kesehatan selama masa pandemi COVID-19. Berdasarkan hasil distribusi penerapan Pedoman Gizi Seimbang (PGS) yang disajikan pada tabel di atas, diketahui bahwa lebih dari setengah responden atau sebanyak 59 orang $(64,1 \%)$ tenaga kesehatan telah menerapkan Pedoman Gizi Seimbang (PGS).

\section{PEMBAHASAN}

Pola Makan Responden di Masa Pandemi COVID-19

Pola makan menjadi salah satu faktor yang telah diteliti dan diketahui dapat bermanfaat dalam menjaga diri dari virus, salah satunya coronavirus disease (COVID-19). Sebagai salah satu upaya dalam penanganan dan pencegahan penularan COVID-19, Kementerian Kesehatan telah meesehatan telah memberikan Pedoman Gizi Seimbang Pada Masa Pandemi COVID-19. Dalam pedoman tersebut, pemerintah mencantumkan beberapa poin penting yang perlu dilakukan untuk menimalisir agar masyarakat tidak tertular dan 
terinfeksi COVID-19 salah satunya adalah terkat pola makan yang baik. (Kementerian Kesehatan RI, 2020).

Pada penelitian ini, peneliti mengadaptasi beberapa poin penting yang perlu diperhatikan selama masa pandemi COVID-10, yaitu sarapan, makan utama, makan selingan (snack), minum air yang cukup, dan penerapan pola makan sesuai isi piringku. Berdasarkan hasil penelitian, diketahui bahwa terkait pola makan responden saat pandemi COVID-19, pola makan sebanyak 59 (64,1\%) responden memiliki pola makan yang sesuai dengan pedoman Gizi Seimbang (PGS) dan 33 responden lainnya $(35,9 \%)$ masih memiliki pola makan yang tidak sesuai dengan PGS.

Pola makan berhubungan dengan beberapa faktor yang dapat memengaruhinya, diantaranya adalah lama kerja dan waktu kerja tenaga kesehatan (Farias et al., 2020). Selain itu, kondisi pandemi seperti saat ini dapat menjadi faktor penyebab lain yang dapat memengaruhi pola makan tenaga kesehatan dikarenakan beban kerja tenaga kesehatan yang meningkat (Blake et al., 2020). Pada penelitian ini, peneliti menemukan bahwa sebanyak 65 orang dari 92 orang $(70,7 \%)$ responden mengatakan bahwa penggunaan APD di masa pandemi COVID-19 ini mengganggu para tenaga kesehatan dalam mengakses ataupun mengonsumsi makanan. Sejalan dengan hal tersebut, penelitian oleh

Benarba, et al. (2020) menyebutkan bahwa tenaga kesehatan ketika telah menggunakan APD maka mereka tidak dapat makan, minum, atau bahkan ke toilet. Hal tersebut dikarenakan penggunaan APD memiliki aturannya sendiri dalam hal penggunaan dan pelepasannya, sehingga ketika APD dilepas maka APD tersebut tidak dapat digunakan kembali kecuali setelah dicuci dengan prosedur khusus (Kemenkes, 2020).

\section{Aktivitas Flsik Responden di Masa Pandemi COVID-19}

Aktivitas fisik dengan melakukan olahraga minimal 3-5 kali seminggu dengan durasi minimal 30 menit merupakan anjuran yang terdapat dalam Pedoman Gizi Seimbang Pada Masa Pandemi COVID-19 yang telah dikeluarkan oleh pemerintah. Menurut penelitian yang telah dilakukan sebelumnya terkat aktivitas fisik, diketahui bahwa melakukan olahraga secara rutin dibutuhkan untuk meningkatkan sistem imun karena dijelaskan bahwa sistem imun akan bersifat lebih responsive dalam melawan virus dan infeksi ketika seseorang melakukan olahraga (Terra et al., 2012; Nieman et al., 2019)

Anjuran untuk melakukan olahraga secara rutin, terkadang banyak diabaikan oleh masyarakat termasuk oleh pekerja tenaga kesehatan. Berdasarkan hasil penelitian, diketahui bahwa sebanyak 54 orang atau $58,7 \%$ tenaga kesehatan memiliki pola aktivitas fisik yang terkategori sesuai dengan pedoman gizi seimbang (PGS). Meskipun begitu, masih lebih dari $40 \%$ responden lainnya memiliki pola 
olahraga yang tidak sesuai jika dibandingkan sengan PGS.

Menurut suatu penelitian, diketahui bahwa di masa pandemi COVID-19 seperti saat ini, masyarakat cenderung lebih mengurangi aktivitas fisik terutama yang dilakukan di luar rumah karena adanya peraturan untuk lebih dianjurkan tetap tinggal di rumah untuk menekan terjadinya penyebaran virus yang lebih meluas lagi (Mattioli et al., 2020). Sebuah penelitian lain yang dilakukan pada tenaga kesehatan ditemukan bahwa terdapat sekitar 76\% tenaga kesehatan tidak melakukan olahraga rutin (Ahmad et al, 2015). Tenaga kesehatan yang memiliki beban kerja dengan keharusan untuk memprioritaskan kesehatan pasien dapat menjadi hambatan tersendiri sehingga masih ada tenaga kesehatan yang belum dapat berolahraga sebagai mana mestinya (Blake et al., 2020)

\section{Waktu Istirahat Responden di Masa Pandemi COVID-19}

Kementerian Kesehatan RI dalam Pedoman Gizi Seimbang (PGS) memebrikan anjuran terkait waktu istirahat yang baiknya diterapkan yaitu minimal $6-8$ jam sehari. Waktu tidur memiliki peranan yang cukup penting untuk tubuh dengan mekanismenya dalam menjaga keseimbangan homeostasis yang dapat memengaruhi kesehatan seseorang (Magnavita, 2014). Walaupun diketahui dampak baik yang akan didapat apabila memiliki waktu tidur yang baik, namun pada praktiknya, masih sedikit orang yang menerapkan pola tidur sehat. Berdasarkan hasil penelitian, diketahui bahwa sebanyak 32 orang atau $34,8 \%$ tenaga kesehatan dengan pola tidur yang terkategori tidak sesuai dengan pedoman gizi seimbang (PGS). Tenaga kesehatan dengan pola tidur yang terkategori sesuai dengan PGS adalah sebanyak 60 orang $(65,2 \%)$ tenaga kesehatan telah memiliki pola tidur yang sesuai dengan PGS.

Sebuah penelitian yang telah dilakukan dengan menggunakan responden tenaga kesehatan di masa pandemi COVID-19, didapatkan bahwa tenaga kesehatan yang bekerja dan kontak langsung dengan pasien di masa pandemi COVID-19 memiliki risiko tinggi untuk mengalami gangguan pola tidur hingga 2,97 kali orang biasa (Lai et al, 2020). Tenaga kesehatan sering mengalami kekhawatiran terkait kesehatan pribadi, menularkan pada anggota keluarga, beban kerja, dan isolasi mandiri menjadi faktor yang dapat mengganggu pola tidur tenaga kesehatan di masa pandemi COVID-19 (Singh et al., 2020).

\section{Penerapan Pedoman Gizi Seimbang di Masa Pandemi COVID-19}

Penelitian ini berkaitan dengan berbagai indikator yang meliputi variabel pola makan, aktivitas fisik, dan waktu istirahat yang keseluruhan data diperoleh secara online dengan penyebaran kuesioner melalui berbagai media. Hasil distribusi terkait penerapan PGS pada responden, diketahui bahwa responden yang menerapkan pedoman gizi seimbang (PGS) 
sebanyak 59 orang atau sekitar $(64,1 \%)$ tenaga kesehatan telah menerpakan PGS selama terjadi pandemi COVID-19.

Sebagai suatu penelitian pendukung, sebuah penelitian dengan menggunakan responden tenaga kesehatan untuk melihat kepatuhannya dalam menerapkan pola makan yang baik, diketahui bahwa dari 1.190 responden, hanya satu orang tenaga kesehatan yang berhasil menerapkan pedoman pola makan USDA Dietary Guidelines (Ahmad et al., 2015). Hal tersebut sama dengan hasil analisis masing-masing variabel yang terdiri atas variabel pola makan, aktivitas fisik, dan waktu istirahat menujukkan bahwa tidak terdapat perubahan yang signifikan pada ketiga variabel tersebut. Ingram et al (2020) dalam penelitiannya mengatakan bahwa orang dewasa cenderung tidak merubah kebiasaan makan mereka.

Penelitian lain bertolak belakang dengan hasil penelitian menyebutkan bahwa perubahan pola makan pada tenaga kesehatan rentan terjadi yang disebabkan oleh beberapa hal, diantaranya keterbatasan dalam mengakses makanan dan rasa tanggung jawab serta beban kerja yang berat pada kondisi darurat hingga banyak dari mereka melewatkan waktu makannya (Gupta et al., 2019; Benarba, 2020). Sebuah penelitian lain juga menyebutkan bahwa dari 20 sampel perawat yang ikut dalam penelitian, 75\% diantaranya menyadari bahwa keterbatasan waktu istirahat yang mereka miliki sangat berhubungan dengan perubahan kebiasaan makan sehingga tenaga kesehatan lebih memiliki untuk makan mengonsumsi makanan ringan (Monaghan et al, 2018). Sebanyak $15 \%$ dari total 126 responden diketahui hampir tidak pernah mengambil waktu makan mereka, bahkan 6\% diantaranya hampir tidak pernah melakukan waktu jeda makan mereka (Faugier et al., 2001)

Berdasarkan hasil penelitian terkait keterbatasan tenaga kesehatan dalam mengakses makanan yang diambil sebelum kondisi pandemi, dapat disimpulkan bahwa sebagian besar tenaga kesehatan telah mengalami masalah dalam menerapkan pola makan tidak hanya di masa pandemi, tetapi sebelum pandemi juga telah terjadi ketidaksesuaian. Hal tersbeut didukung oleh penelitian yang dilakukan oleh Ahmad (2015) yang mengatakan bahwa dari 1.190 tenaga kesehatan, hanya satu orang yang telat menerapkan pola makan sesuai USDA Dietary Guidelines sedangkan sebanyak $76 \%$ tidak melakukan aktivitas fisik, $71,5 \%$ bekerja $>48$ jam/hari, dan lebih dari 50\% tenaga kesehatan memiliki jam tidur $<7$ jam/hari. Oleh karena itu, perubahan yang mereka alami ketika terjadi di masa pandemi tidak terlalu berdampak secara signifikan pada kepatuhan tenaga kesehatan dalam menerapkan pola hidup sesuai PGS.

\section{KESIMPULAN}

Pola makan responden dengan pola makan yang sesuai dengan PGS adalah sebanyak 64\%, aktivitas fisik pada kategori sesuai PGS adalah 
sebanyak 54\% dari keseluruhan responden, dan pada waktu istirahat adalah sebesar $65,2 \%$.

Penerapan pedoman gizi seimbang saat terjadi pandemi COVID-19 terdapat 59 tenaga kesehatan (64,51\%) yang terkategori telah sesuai dengan pedoman gizi seimbang (PGS) sedangkan 33 tenaga kesehatan lainnya terkategori tidak sesuai dengan PGS.

Evaluasi secara keseluruhan terkait hasil penelitian, penerapan pola makan, aktivitas fisik, dan waktu istirahat cukup baik namun perlu ditingkatkan lagi mengingat pentingnya kebutuhan gizi yang baik terutama di masa pandemi COVID-19. Selain itu, eksplorasi penelitian pendukung perlu terus dikembangkan mengingat masih minimnya penelitian pendahulu terkat gizi di masa pandemi.

\section{PENUTUP}

Terima kasih diucapkan kepada semua pihak yang telah mendukung dan membantu peneliti dalam menyelesaikan artikel ini, Kepada para dosen yang telah membantu dan membimbing peneliti sehingga dapat menyelesaikan artikel ini. Begitu juga kepada seluruh pihak yang telah membantu dalam proses pengambilan data.

\section{DAFTAR PUSTAKA}

Ahmad, W., Taggart, F., Shafique, M. et al (2015) 'Diet, Exercise And MentalWellbeing Of Healthcare Professionals

\author{
(Doctors, Dentists And Nurses) In \\ Pakistan', Peer J. doi: DOI \\ 10.7717/peerj.1250.
}

Barrer, ES., Horton, DB., et al (2020)

'Prevalence Of SARS-Cov-2 Infection In

Previously Undiagnosed Health Care

Workers At The Onset Of The U.S. COVID19 Epidemic', medRxiv.

Benarba, B. dan G. A. (2020) 'Pre-Exposure And Post-Exposure New Prophylactic Treatments Against COVID-19 In Healthcare Workers', The North African Journal of Food and Nutrition Research, 4(07), pp. 260-7.

Blake, H., Bermingham, F. et al (2020) 'Mitigating the Psychological Impact of COVID-19 on Healthcare Workers: A Digital Learning Package', International Journal of Environment Research and Public Health, 17. doi: doi:10.3390/ijerph17092997.

COVID-19, G. T. P. P. (2020) Situasi Virus COVID19 di Indonesia. Available at: https://covid19.go.id/ (Accessed: 10 August 2020).

COVID-19, J. T. (2020) Dashboard COVID-19 Jawa Timur, Pemerintah Provinsi Jawa Timur. Available at: https://infocovid19.jatimprov.go.id (Accessed: 10 August 2020). Faugier, J., Lancaster, PD., Dobson, K. (2001) 'Barriers To Healthy Eating In The Nursing Profession: Part 1', Nurs Stand, 15, pp. 
$33-6$.

Gupta, CC., Coates, A. et al (2019) 'The Factors Influencing The Eating Behaviour Of Shiftworkers: What, When, Where And Why', Industrial Health, 57, pp. 419-453.

Hafeez, A., Ahmad, S., Siddqui, S. et al (2020) 'A Review of COVID-19 (Coronavirus Disease-2019) Diagnosis, Treatments and Prevention', EJMO, 4(2), pp. 116-125.

Lai, DJ., Ko, NY., Chen, Y. et al (2020) 'COVID-19Related Factors Associated with Sleep Disturbance and Suicidal Thoughts among the Taiwanese Public: A Facebook Survey', Int. J. Environ. Res. Public Health, 17.

Magnavita, N. (2014) 'Workplace Violence And Occupational Stress In Healthcare Workers: A Chicken-And-Egg SituationResults Of A 6-Year Follow-Up Study', J Nurs Scholarsh, 46(5), pp. 366-76.

Mattioli, A., Sciomer, S. et al (2020) 'Quarantine During COVID-19 Outbreak: Changes In Diet And Physical Activity Increase The Risk Of Cardiovascular Disease', Nutrition, Metabolism \& Cardiovascular Disease. Available at: https://doi.org/10.1016/j.numecd.2020.0 5.020

Mhango, M., Dzobo, M. et al (2020) ‘COVID-19 Risk Factors Among Health Workers: A Rapid Review.', Safety and Health at Work.

Monaghan, T., Dinour, L. et al (2018) 'Factors
Influencing The Eating Practices Of Hospital Nurses During Their Shifts', Workplace Health Saf, 66, pp. 331-42.

Nieman, DC dan Wentz, L. (2019) 'The Compelling Link Between Physical Activity And The Body's Defense System', Journal of Sport and Health Science, 8, pp. 2012017.

RI, kementerian K. (2020) Petunjuk Teknis alat Pelindung Diri (APD) Dalam Mengahadapi Wabah. Jakarta.

RI, K. K. (2020) Panduan Gizi Seimbang pada Masa Pandemi COVID-19. Jakarta: Kementerian Kesehatan RI.

Kementerian Kesehatan RI, 2020. Pedoman Pencegahan dan Pengendalian Coronavirus Disease (COVID-19). Jakarta: Kemneterian Kesehatan Republik Indonesia.

Sahu, AK., Mathew, R. et al (2020) 'COVID-19 In Health Care Workers - A Systematic Review And Meta-Analysis', American journal of Emergency Medicine, 38, pp. 1727-1731.

Singh, M., Sharda., S. et al (2020) ‘Optimal Sleep Health Among Frontline Healthcare Workers During The COVID-19 Pandemic', Can J Anesth / J can Anesth. Available at: https://doi.org/10.1007/s12630-02001716-2.

Terra, R., Silva, S. et al (2012) 'Effect Of Exercise On The Immune System: Response, Adaptation And Cell Signaling', Rev Bras 
Med Esporte, 18(3).

World Health Organization (WHO) (2020) WHO

Coronavirus Disease (COVID-19)

Dashboard. Available at:

https://covid19.who.int/ (Accessed: 15

December 2020).

Yuliana (2020) 'Corona Virus Disease (COVID-

19); Sebuah Tinjauan Literatur', Wellness

and Healthy Magazine, 2(1), pp. 187-192.
Zhang, J., Lai, S. et al (2020) 'Diet and Nutrition of Healthcare Workers in COVID-19 Epidemic-Hubei, China, 2019', China CDC Weekly, 2(27).

Kementerian Kesehatan Republik Indonesia. 2014. Peraturan Menteri Keseatan RI Nomor 41 Tahun 2014 Tentang Pedoman Gizi Sembang. Diakses pada 14 Agustus 2020 